\title{
Scramsis Game (Syntak Scramble) Innovation Of Basic Programming Educational Games For Students Of Class X Tkj Smk Muhammadiyah 1 Wates
}

\author{
Ahmad Muzaki Salman Alfaris \\ Informatics Engineering Education Study Program, Faculty of Engineering, Universitas negeri yogyakarta
}

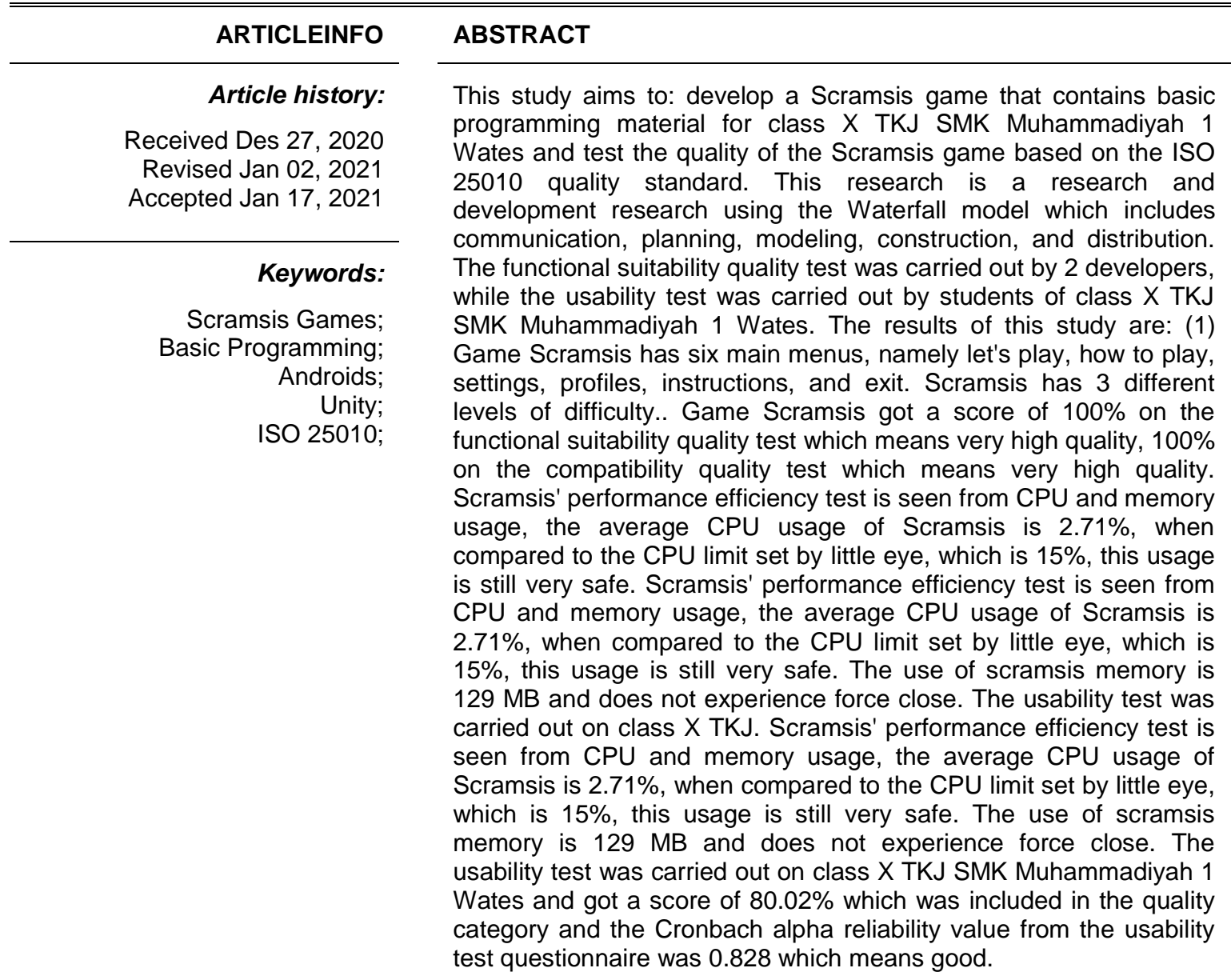

This is an open access article under the CC BY-NClicense.

\section{Corresponding Author:}

Ahmad Muzaki Salman Alfaris

Informatics Engineering Education Study Program,

Faculty of Engineering, Universitas negeri Yogyakarta

E-mail:ahmadmizaki@gmail.com

\section{INTRODUCTION}

Indonesian people are already familiar with the game. Game is an activity that is done to get pleasure for its users. This makes gaming an activity that is considered bad to do because it only 
provides fun and can override the education that should be done. In addition, games can also cause addiction effects, this causes users to forget their obligations that should be done first. The results of the analysis showed that adolescents who played violent games for several years experienced increased aggression during the study, whereas adolescents who played non-violent games were not shown to experience increased aggression.increased aggression (Siddiqa, 2010).

Educational games are games that contain learning material content and are designed to stimulate or provoke students' thinking power, including increasing students' concentration so that they can solve problems in the game (Reali \& Anggraini, 2016). Educational games are media that can provide teaching, increase knowledge, increase logical thinking power and creativity for users through a unique and interesting educational game. This educational game can be used by Vocational High School (SMK) students as a means of practicing and testing how much students understand the material that has been delivered in class, especially in rote material.(Astuti, 2012).

Based on the results of interviews conducted on August 7, 2019 with Mr. Iwan Junaedi, ST as a teacher of the Network Service Technology (TLJ) subject at SMK Muhammadiyah 1 Moyudan, students have difficulty understanding the competence of Data Communication Standards. Students who do not understand the material are ashamed to ask the teacher. This is indicated by the fact that when the teacher gives the opportunity to ask questions, not many students ask questions. When the teacher asks questions, students wait for the teacher to appoint before answering. Another problem is the lecture method used by the teacher is still not effective. The implementation of learning is still running in one direction and is monotonous so that student learning activity is still low. Plus,

Various learning problems that have been stated above can be overcome with the help of multimedia. Learning using multimedia will be more fun and can make students more active. Educational games are one of the multimedia combined with education, both learning materials in schools or educational materials in general. In addition, educational games are very interesting for students to use because the design of educational games is very unique and varied. With multimedia or educational games, the material will be easy to understand because more senses are used to capture existing information (Aparicio, Bacao, \& Oliveira, 2016)

By utilizing the concept of educational games and the android operating system developed using the Unity 3D Engine, learning by using educational games on basic programming materials can be done very interestingly and funly in any conditions and situations both at school and outside of school, so that some problems that usually occur in schools such as students having difficulty in learning understanding the material and the lack of interest in the learning delivered by the teacher will be helped by the existence of educational games(Reali \& Anggraini, 2016).

\section{METHOD}

\subsection{Development Procedure}

The development procedure in this research is to use the Waterfall model. The waterfall model is good to use in this study because it is simple and has clear stages. The waterfall development model has several stages starting from communication, planning, modeling, construction, and ending with distribution to end users. The stages in the waterfall model must be passed well, because each stage has an important and influential role in the next stage. The waterfall development model is systematic using only limited resources, so this development model is good for use in the development of the basic programming Scramsis educational game.

a. Communication Stage

At the communication stage, observations were made at the Muhammadiyah 1 Wates Vocational School and interviews with teachers of basic programming subjects. Observations were made, namely observing the condition of the school, class, and students followed by communicating with the teacher as a student facilitator. Interviews were conducted by asking questions in the form of gaps in learning and what problems often occur in schools. From the results of these interviews, various kinds of problems will be obtained which will later be sought for solutions and developed in the future planning stage. 
b. Planning Stage

Based on the results of information collection carried out at the communication stage with the school, there will be many problems obtained. Furthermore, an idea is made to develop products that can help students in learning. Next, planning is carried out to determine the development schedule to be carried out, the schedule is compiled based on the completion time limit and what activities need to be carried out.

c. Modeling Stage

The modeling stage, which is the design stage of the software, aims to produce an overview of the system which will later function at the construction stage. The modeling stage consists of making UML, flowchart, storyboard, and interface design.

d. Construction Stage

Writing code based on the results in the previous modeling stage, writing stage code is done to provide functionality to each design that has been made. Code writing is done using the $C$ language on the Unity game engine. Then a series of tests are carried out to determine the feasibility and quality of the program. There are several types of test tests, namely feasibility tests which include media feasibility tests and material feasibility tests. The quality test is based on the ISO 25010 standard and focuses on 4 aspects, namely functional suitability, usability, compatibility, and performance efficiency.

e. Distribution Stage

The distribution stage is the last stage in the manufacture of application products. The purpose of distribution is to promote the product so that it can be accepted by users both individually, in groups and institutions in this case is a school. The product is built into a file with the .aab extension so that it can be uploaded to a marketplace called Google Play.

\subsection{Data Collection Method}

a. Observation

Observation is a way to get information by observing the object to be studied. Observations in this study were carried out by looking directly at the conditions related to learning. The aspects that were observed were the condition of the school, students while studying, the way the teacher delivered it, and the facilities used.

b. Interview

Interviewing is one way to get deeper information by asking the interviewees the questions needed in the research. According to Eko Putro Widoyoko (2012:40) the interview is an oral dialogue between the interviewer and the respondent with the intention of getting the information needed.

c. Questionnaire

Questionnaire or questionnaire is one of the methods used to obtain data by giving various questions to respondents. There are two types of questionnaires that are often used, namely open questionnaires and closed questionnaires. The open questionnaire was carried out by giving a list of questions to the respondents and then answering them freely, while in the closed questionnaire respondents were given questions and answer choices so that they only answered according to the answers provided. Questionnaires are used to collect data on media feasibility testing aimed at two material experts and two media experts as well as software quality testing which includes usability aspects with 18 respondents and functionality aspects with 2 developers.

\section{RESULTS AND DISCUSSIONS}

\subsection{Results}

The result of this research is a mobile apps application product in the form of an educational game Scramble Syntax (Scramsis) which is intended for students of class X TKJ SMK Muhammadiyah 1 Wates in particular, and class X SMK students throughout Indonesia in general who use the 2013 curriculum. 
a. Feasibility test

Feasibility tests are carried out to determine whether the media is appropriate or not to be used in the study. The feasibility test was carried out on Network Computer Engineering teachers as material experts and senior teachers appointed by the head of the department and considered competent as media experts, this feasibility test was carried out at the Muhammadiyah 1 Wates Vocational School.

b. Material feasibility test

The material feasibility test is carried out to find out the material used in the media in accordance with the material in the Basic Programming subject. The results of material testing which include aspects of material and instructional content can be seen in the following table:

Table 1.

Material Feasibility Test Results

\begin{tabular}{clcc}
\hline \multirow{2}{*}{ No. } & \multirow{2}{*}{ Aspect } & \multicolumn{2}{c}{ Expert Assessment Results } \\
\cline { 2 - 4 } & & Expert 1 & Expert 2 \\
\hline 1 & Contents & 37 & 35 \\
2 & Instructional & 24 & 21 \\
\hline Total & & 61 & 56 \\
\hline
\end{tabular}

From the results obtained, the average calculation can be done value with the divisor of the number of statements as much as 13 in the feasibility test questionnaire, then compared with the assessment classification, the following is the average calculation value of each expert:

$$
\text { Expert Avera }{ }_{13}^{61}=4,69
$$

Expert Average $2=\frac{56}{13}=4,30$

c. Media Feasibility Test

This test was conducted to determine the feasibility of the media in terms of appearance. The examiners are 2 senior teachers at SMK Muhammadiyah 1 wates who are appointed directly by the head of the department and are considered to have the ability to assess media well. The two examiners were Mr. Tuhadi and Mrs. Peni Akhadiyah. The results of the media feasibility test can be seen in table 9 .

Table 2.

Media Feasibility Test Results.

\begin{tabular}{lccc}
\hline \multirow{2}{*}{ No. } & \multirow{2}{*}{ Aspect } & \multicolumn{2}{c}{ Expert Assessment Results } \\
\cline { 3 - 4 } & & Expert 1 & $\begin{array}{c}\text { Expert } \\
\mathbf{2}\end{array}$ \\
\hline 1 & Appearance & 43 & 43 \\
Total & & 43 & 43 \\
\hline
\end{tabular}

The data obtained from the assessment results were then calculated on average with a divisor of 10 as the number of statements in the media feasibility test questionnaire. The results of the average calculation are as follows:

$$
\begin{aligned}
& \text { Expert Average } 1=-43=4.30 \\
& 10 \\
& \text { Expert Average } 2=\underline{43}=4.30 \\
& \text { Total Average }=^{43+43}=4.30
\end{aligned}
$$


Thus, the feasibility test for the Scramsis game material gets a total average score of 4.30 in the Very Eligible category

\subsection{Software Quality Test}

a. Functional Suitability Test

This test is carried out to determine whether the function of the application in the form of button functions, music functions, the function of each page is running without any errors. The completed application was then tested by 2 experts, Fikri Abdullah Aziz as an expert in game development and Tri Nugroho as an expert in front-end developer.

Based on the test results listed in the attachment. Then the percentage of application success is calculated.

Expert Percentage $1=\frac{21}{21} \times 100 \%=100 \%$

b. Compatibility Test

Compatibility tests were carried out on 5 different devices with different android operating systems. The five devices tested were Lenovo A6000, Lenovo A6600, Xiaomi Redmi Note 5A, Moto G5S plus XT1805, and Xiaomi Redmi Note 5 with android operating systems namely Lollipop, Marshmallow, Nougat, Oreo, and Pie.

\section{CONCLUSION}

The conclusion obtained from the research and development of the Scramsis Game (Syntax Word Scramble) Basic Programming Educational Game Innovation for Class X TKJ SMK Muhammadiyah 1 Wates Students is that the Scramsis Game can overcome the lack of development of educational games that contain basic programming material in schools. The Scramsis game containing material for introducing $\mathrm{C}_{++}$programming syntax can help class $\mathrm{X}$ TKJ SMK Muhammadiyah 1 Wates students in understanding basic programming material that is considered difficult. Game Scramsis has met the ISO 25010 quality standard which includes 4 aspects, namely functional suitability, compatibility, performance efficiency, and usability. In the functional suitability aspect, the Scramsis game gets a score of $100 \%$ in the Very Qualified category. On the compatibility aspect, tested on 5 different smartphones with Android versions namely Lollipop, Marshmallow, Nougat, Oreo, and Pie. Game Scramsis gets a score of $100 \%$ in the Very Quality category. In terms of performance efficiency in terms of memory and CP, the Scramsis game gets an average CPU usage of $2.71 \%$ and an average memory usage of $129 \mathrm{MB}$. The usability aspect of the Scramsis game that was tested on TKJ students of SMK Muhammadiyah 1 Wates got a score of $80.2 \%$ in the Quality category. Furthermore, the reliability value of Cronbach's alpha from the questionnaire used got a score of 0.828 . Thus, the questionnaire used in the assessment is included in the Good category.

\section{References}

Aparicio, M., Bacao, F., \& Oliveira, T. (2016). An e-learning theoretical framework. An E-Learning Theoretical Framework, (1), 292-307.

Astuti, R. (2012). Pembelajaran IPA dengan Pendekatan Ketrampilan Proses Sains menggunakan Metode Eksperimen Bebas Termodifikasi dan Eksperimen Terbimbing Ditinjau dari Sikap Ilmiah dan Motivasi Belajar Siswa (Pokok Bahasan Limbah dan Pemanfaatan Limbah Kelas XI Semes. UNS (Sebelas Maret University).

Reali, C., \& Anggraini, Y. D. (2016). Pengaruh Game Kekerasan terhadap perilaku agresif anak. Permata: Jurnal Pendidikan Anak Usia Dini, 1(1), 8-17.

Siddiqah, L. (2010). Pencegahan dan penanganan perilaku agresif remaja melalui pengelolaan amarah (anger management). Jurnal Psikologi, 37(1), 50-64. 